\title{
An Analysis of the Socio-Economic Characteristics of the Semi-Subsistence Farms that Applied for Non- Refundable EU Funds in the North-Western Romania
}

\author{
Manuela Carmen SIMU ${ }^{1 *}$, Diana-Elena DUMITRAȘ ${ }^{1}$,Valentin MIHAI $^{1}$, Ionel-Mugurel JITEA ${ }^{1 *}$ \\ ${ }^{1}$ University of Agricultural Sciences and Veterinary Medicine Cluj-Napoca, 3-5 Calea Mănăștur, Cluj- \\ Napoca, Romania. \\ *)corresponding author, e-mail: mjitea@usamvcluj.ro
}

BulletinUASVM Horticulture 72(2) / 2015

Print ISSN 1843-5254, Electronic ISSN 1843-5394

DOI:10.15835/buasvmcn-hort:11702

\begin{abstract}
Romania joined the European Union (EU) with a farming structure dominated in terms of numbers by small subsistence and semi-subsistence farms (2007). Through the second Common Agricultural Policy (CAP) pillar they were supported by a special programme to become more economic resilient. In order to see the potential outcome of that program, 202 farms from North-West Romanian development region were investigated by face-to-face interviews using a structured questionnaire. Results show that more than 60 per cent have farm managers bellow 50 years old with good technical educational background. Their future-self assessment looks optimistic because more than 64\% want to invest using EU funds in the future (in the period 2014 and 2020). Farmers who want to quit farming perceive market access and their age as being the main limitative factors.
\end{abstract}

Keywords: Common Agricultural Policy, future self-assessment, semi-subsistence farms.

\section{Introduction}

Nowadays, the European agriculture is developed around other key concepts on the idea of long-run sustainability (Lamine, 2015). It represents the process of developing an economic, social, environmental and technical resilient farming sector. The CAP was reformed in the last years (2003 and 2013) to achieve, between others, also this strategic goal (O'Riordan and Voisey, 2013). When Romania joined the European Union the agricultural sector was dominated by a large number of subsistence and semisubsistence farms, totally different as compared with the Western ones (Mathijs and Noev, 2004). They applied low-input environmental friendly techniques that proved to be economically and socially unsustainable (Fischer et al., 2012). Through the second CAP pillar such farms were supported by Measure 141 - 'Supporting the semi - subsistence farms' to increase their economical size with 1,500 euros on a four year investment period (RNRDP, 2013).

\section{Aims and objectives}

The paper aims to assess the potential outcomes of this programme based on the farmer future self-assessment. It investigates if the farmers intend to continue farming after the end of the 2007 - 2014 financing period, examining the main reasons in the case of choosing to end the farming activity.

\section{Materials and methods}

A questionnaire with twenty one questions was implemented by face-to-face interviews between September 2014 and February 2015 in the North-Western Romanian development region. The questionnaire was divided in three sections. The first one comprises questions about the farm technical-orientation and socio- 
Tab. 1. Descriptive statistics of the main socio-economic characteristics of the farms that applied for the semi-subsistence Romanian Rural Development measure (N-W Romanian Region)

\begin{tabular}{|c|c|c|c|c|c|c|c|}
\hline \multicolumn{2}{|c|}{ Characteristics } & \multirow{2}{*}{$\frac{\mathrm{N}}{16}$} & \multirow{2}{*}{$\begin{array}{c}\% \\
7.9 \\
\end{array}$} & \multicolumn{2}{|c|}{ Characteristics } & \multirow{2}{*}{$\frac{N}{122}$} & \multirow{2}{*}{$\begin{array}{c}\% \\
60.4 \\
\end{array}$} \\
\hline \multirow{5}{*}{ Age } & $<30$ years old & & & Income - farming & Yes & & \\
\hline & 30-39 years old & 39 & 19.3 & as main source & No & 80 & 39.6 \\
\hline & 40-49 years old & 72 & 35.6 & \multirow{7}{*}{$\begin{array}{c}\text { Income - Other } \\
\text { sources }\end{array}$} & Child raising allowance & 8 & 3.4 \\
\hline & 50-59 years old & 34 & 16.8 & & Child state allowance & 64 & 31.7 \\
\hline & $>59$ years old & 41 & 20.3 & & Salary & 85 & 42.1 \\
\hline \multirow{6}{*}{ Education } & $<8$ grades & 3 & 1.5 & & Unemployment benefit & 9 & 4.5 \\
\hline & 8-10 grades & 42 & 20.8 & & Pension & 41 & 20.3 \\
\hline & Vocational school & 58 & 28.7 & & Other sources (subventions) & 17 & 8.4 \\
\hline & High school & 59 & 29.2 & & Non-response & 34 & 16.8 \\
\hline & University & 18 & 8.9 & \multirow{2}{*}{ Gender } & Male & 135 & 66.8 \\
\hline & Non-response & 22 & 10.9 & & Female & 67 & 32.2 \\
\hline
\end{tabular}

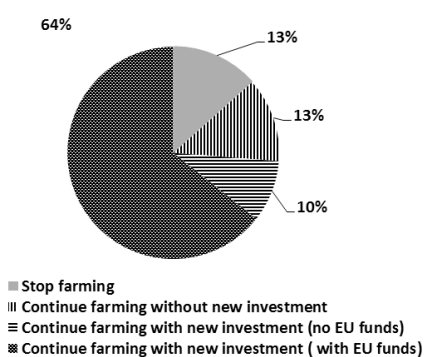

Fig. 1. Farm future self-assessment

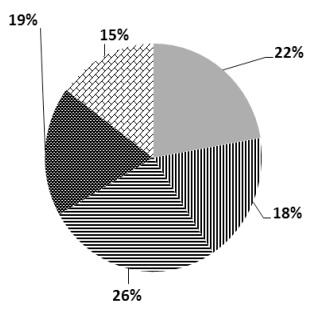

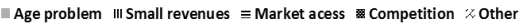

Fig. 2. Reasons for quitting farming

economic profile. The second part addressed the type of subsidies received in the last 5 years (2014 the last agricultural year) and the type of investment programs accessed in the second CAP pillar. The last part deals with the future of the farm. The farmers were asked if they want to continue farming and about the main reasons that force them to think about quitting it. The sample size was calculated using the Yamane formula knowing that farms are homogeneous in size due to the Rural Development Programs demands (Israel, 2013):

$$
n=N /\left(1+N e^{2}\right) n=N /\left(1+N e^{2}\right)
$$

Where: $\mathrm{n}$ is the sample size (200 farms); $\mathrm{N}$ is the population size $(11,717$ farms applied between 2007 and 2014 for 141 Measure in the N-W Romanian region accordingly to the Romanian Agency for Financing the Rural Investments); $e$ is the sampling error (7\% due to financial constraints). 202 farms were identified and investigated based on a governmental database. They were selected using simple random sample techniques. Descriptive statistics was used for data analysis.

\section{Results and Discussion}

The main socio-economic characteristics show that $35 \%$ of farms have managers that are between 40 and 49 years old (Tab.1). Most of them graduated vocation or high schools and for about $60 \%$ agriculture represents the main income source.

The future self-assessment shows that $64 \%$ of farmers intend to develop their farm in the future and only $13 \%$ want to quit farming (Fig. 1). For the last ones, the market access (26\%) and the age $(22 \%)$ are the most common negative issues that make them to think leaving the business (Fig.2).

\section{Conclusion}

The assessment of the measure designed to increase the economic resilience of the semisubsistence Romanian farms showed that the main socio-economic characteristics allow rather good long-run sustainability. Moreover, farms 
want to continue the business growth in the near future that proved that the program achieved its main goals.

\section{References}

1. Fischer J, Hartel T, Kuemmerle T (2012). Conservation policy in traditional farming landscapes. Conservation Letters 5(3): 167-175.

2. Istrael G (2013). Determining Sample Size. PEOD6, Agricultural Education and Communication Department. University of Florida: 1- 5. On-line: https://edis.ifas.ufl. edu/pdffiles/PD/PD00600.pdf (last accessed September 2015).
3. Lamine C (2015). Sustainability and resilience in agrifood systems: reconnecting agriculture, food and the environment. Sociologia Ruralis 55(1): 41-61.

4. Mathijs E, Noev N (2004). Subsistence farming in Central and Eastern Europe : Empirical evidence from Albania, Bulgaria, Hungary, and Romania. Eastern European Economics 42(6): 72-89.

5. O'Riordan T ,Voisey H (2013). Transition to sustainability: The politics of Agenda 21 in Europe. Routledge: 1-336.

6. Romanian National Rural Development Plan (RNRDP) (2013). Romanian Government. Bucharest: 1 - 430. 